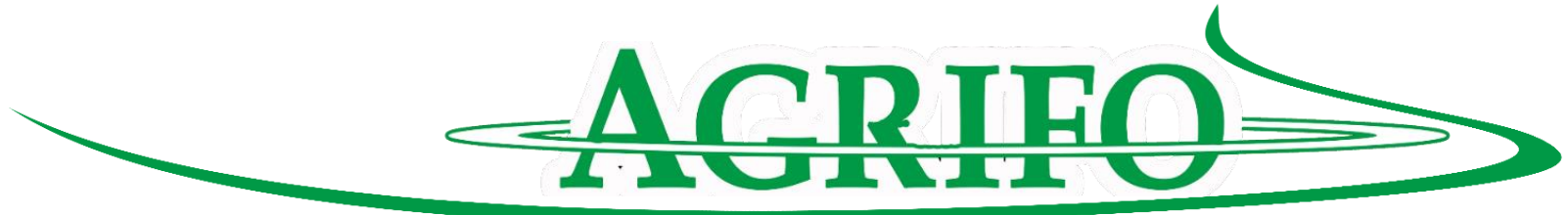

\title{
ANALISIS POTENSI WILAYAH DALAM PENGEMBANGAN PETERNAKAN SAPI POTONG DI KECAMATAN SIJUNJUNG KABUPATEN SIJUNJUNG
}

\author{
Nova Anggraini ${ }^{1}$, Riza Andesca Putra ${ }^{2}$ \\ email: rizaandescaputra18@gmail.com
}

\section{ABSTRAK}

Tujuan penelitian ini adalah (1) Mengetahui potensi sumber daya manusia peternakan sapi potong di Kecamatan Sijunjung. (2) Mengetahui ketersediaan fasilitas pendukung untuk pengembangan peternakansapi potong di Kecamatan Sijunjung. (3) Mengetahui potensi lahan dan pakan di Kecamatan Sijunjung terhadap pengembangan peternakan sapi potong. (4) Mengetahui kemampuan wilayah Kecamatan Sijunjung dalam pengembangan peternakan sapi potong. Penelitian dilaksanakan di Kecamatan Sijunjung yaitu berlangsung pada bulan Januari - Juli 2016. Penelitian ini menggunakan metode studi pustaka dan survey.

Berdasarkan hasil penelitian, maka dapat diambil kesimpulan bahwa Kecamatan Sijunjung memiliki karakter sumber daya manusia peternak yang tergolong cukup baik dalam upaya pengembangan sapi potong. Hal tersebut berdasarkan pada bahwa umumnya berusia produktif $(82,05 \%)$, rata-rata berpendidikan SMP $(51,28 \%)$, sapi yang dipelihara merupakan milik sendiri $(69,23 \%)$, berjenis kelamin perempuan $(53,85 \%)$, dengan rata-rata jumlah ternak yang dimiliki 1-5 ekor $(79,49 \%)$, dan memiliki pengalaman beternak $<5$ tahun $(66,67 \%)$. Walaupun fasilitas pendukung peternakan seperti Puskeswan dan RPH/TPH pada umumnya belum sesuai ketentuan kecuali PosULIB. Kecamatan Sijunjung tidak memiliki pasar ternak, pada umumnya kelompok tani ternak adalah kelompok lanjut (55,32\%), tidak ada asosiasi peternak, dan terdapat 1 Bank Pemerintah, 1 Bank Pembangun daerah, 2 Bank Swasta, 2 Bank Perkeriditan Rakyat dan 50unit koperasi yang tersebar di seluruh Kecamatan Sijunjung. Namun Nilai Indeks Daya Dukung (IDD) pakan di Kecamatan Sijunjung adalah 8,23, artinya IDD $>2$ berada di wilayah aman dalam pengembangan peternakan sapi potong. Wilayah mampu dalam menampung ternak ruminansia adalah 24.816,248 ST. Saat ini populasi ternak sebanyak 6.030,68 ST, sehingga bisa dilakukan penambahan ternak sebanyak 18.785,568 ST. Untuk populasi sapi potong dapat dilakukan penambahan sebanyak 3.615,54 ST.

Kata Kunci: Potensi, Pengembangan, Sapi Potong

\footnotetext{
${ }^{1}$ Mahasiswi Sekolah Tinggi Ilmu Pertanian (STIPER) Sawahlunto Sijunjung Sumatera Barat

${ }^{2}$ Staff Pengajar Sekolah Tinggi Ilmu Pertanian (STIPER) Sawahlunto Sijunjung Sumatera Barat
} 


\section{PENDAHULUAN}

Pembangunan peternakan memiliki prospek yang semakin cerah dimasa depan karena permintaan bahan baku yang berasal dari ternak (daging, telur dan susu) semakin meningkat seiring meningkatnya jumlah penduduk. Hal ini ditunjang juga dengan meningkatnya angka pendapatan perkapita dan kesadaran masyarakat untuk mengkonsumsi pangan yang bergizi tinggi.

Meningkatkan produksi daging merupakan salah satu upaya untuk mewujudkan ketahanan pangan sekaligus memajukan tingkat kecerdasan sumber daya manusia Indonesia. Daging sapi adalah sumber protein hewani yang kontribusinya dalam memenuhi kebutuhan konsumen nasional sangat penting. Produktivitas yang rendah merupakan kendala peningkatan produksi daging terutama pada usaha sapi potong rakyat. Keterbatasan modal, kurang berwawasan agribisnis serta tatalaksana pemeliharaan yang masih tradisional merupakan penyebab rendahnya produktivitas, dengan tingkat pertumbuhan dibawah 0,5 $\mathrm{kg} / \mathrm{hari}$ (Utomo dkk, 1999).

Salah satu daerah di Sumatera Barat yang juga dijadikan kawasan pengembangan sapi potong adalah Kabupaten Sijunjung.Jumlah populasi sebanyak 17.443 ekor pada tahun 2014 (Dinas Peternakan Kabupaten Sijunjung.2014).Sijunjung merupakan daerah yang cukup potensial dan mempunyai potensi yang baik untuk pengembangan ternak sapi potong.

Kecamatan Sijunjung merupakan salah satu kecamatan yang ada di Kabupaten Sijunjung yang menghasilkan ternak sapi potong yang cukup besar setelah Kecamatan
Koto VII dengan jumlah populasi sebesar 3.691 ekor (Dinas Peternakan Kabupaten Sijunjung, 2014). Berdasarkan survey awal penulis sebagian besar peternakan sapi potong yang ada di Kecamatan Sijunjung masih merupakan jenis usaha rakyat, yaitu sistem pemeliharaan masih bersifattradisional dan merupakan usaha sambilan disamping sebagai petani di sawah. Dari hasil wawancara penulis dengan Dinas Peternakan Kabupaten Sijunjung bahwa tingkat pendidikan dan keterampilan petani yang rendah berpengaruh terhadap tatalaksana pemeliharaan dan produksi peternakan sapi potong. Wilayah Kecamatan Sijunjung didominasi oleh hutan $(52,71 \%)$, sawah $(4,49 \%)$, perkebunan, tanah terbuka, perumahan,semak belukar. Untuk itu perlu adanya data tentang potensi wilayah dalam penyediaan pakan. Darmono (1993) mengatakan, pakan ternak untuk budidaya sapi merupakan faktor yang penting untuk meningkatkan produksi. Jika pemanfaatan akan potensi yang tersedia kurang, maka akan menyebabkan produktivitas usaha ternak sapi potong akan menurun dan menyebabkan penurunan produksi.

Berdasarkan uraian tersebut, diperlukan adanya suatu penelitian yang mengkaji tentang analisis potensi wilayah dalam pengembangan peternakan sapi potong, oleh sebab itu penulis tertarik melakukan penelitian tentang"Analisis Potensi Wilayah dalam Pengembangan Peternakan Sapi Potong di Kecamatan Sijunjung Kabupaten Sijunjung".

\section{METODOLOGI PENELITIAN}

\section{Tempat dan Waktu Penelitian}

Penelitian ini dilaksanakan di nagari yang ada di Kecamatan Sijunjung. Lokasi Penelitian dipilih 
secara sengaja(purposive) yakni 2 (dua) nagari yang memiliki ternak sapi potong tertinggi dan terendah di Kecamatan Sijunjung, maka 2 (dua) nagari terpilih yaitu Nagari Pematang
Waktu Penelitian yaitu selama 7 bulan, dihitung sejak persiapan awal penelitianhingga penulisan hasil penelitian (Januari - Juli 2016).

\section{Metode Penelitian}

Penelitian ini menggunakan metode studi pustaka dan survey. Studi pustaka yaitu dilakukannya pengumpulan data dan laporan dari Dinas Peternakan dan Perikanan Kabuapeten Sijunjung, Badan Pusat Statistik Kabupaten Sijunjung, instansi yang terkait lainnya. Survey dilakukan dengan pengamatan dan wawancara langsung dengan masyarakat peternakan Kabupaten Sijunjung.

\section{Populasi dan Sampel}

Populasi pada penelitian ini adalah seluruh peternak sapi potong di dua nagari terpilih. Sampel adalah bagian dari jumlah dan karakteristik yang dimiliki oleh populasi tersebut. Sampel yang diambil dari populasi harus betul-betul representatif(mewakili). Penentuaan jumlah sampel dilakukan dengan cara penghitungan statistik yaitu dengan menggunakan Rumus Slovin.Rumus Slovindigunakan untuk menentukan ukuran sampel dari populasi yang telah diketahui jumlahnya sebanyak 349 kepala keluarga (KK), yaitu Nagari Pematang Panjang dan Silokek yang masing-masing $313 \mathrm{KK}$ dan $36 \mathrm{KK}$. Untuk tingkat presisi yang ditetapkan dalam penentuan sampel adalah $15 \%$.

Rumus Slovin:
$n=\frac{N}{1+N(e)^{2}}$

Keterangan:

$\mathrm{n} \quad=$ Ukuran sampel

$\mathrm{N}=$ Ukuran Populasi

e $=$ Kelonggaran ketidak telitian

karena kesalahan pengambilan sampel yang dapat ditolerir, kemudian di kuadratkan. (Sugiyono, 2010).

Berdasarkan Rumus Slovin, maka besarnya penarikan jumlah sampel penelitian adalah :

$$
\begin{aligned}
n & =\frac{N}{1+N(e)^{2}} \\
& =\frac{349}{1+3490.15^{2}}=39.4
\end{aligned}
$$

Sehingga dibulatkan menjadi 39 KK

Untuk menentukan besarnya sampel dari masing - masing nagari dilakukan dengan menggunakan rumus alokasi proporsional.

Jumlah sampel tiap nagari = $\frac{\text { Populasi Nagari }}{\text { Total Populasi }} x$ Jumlah Sampel

Sampel di Nagari Pematang Panjang

$=\frac{313}{349} \times 39=35 \mathrm{KK}$

Sampel di Nagari Silokek

$=\frac{36}{349} \times 39=4 \mathrm{KK}$

\section{Variabel Penelitian}

1. Untuk menjawab tujuan peneltian yang pertama tentang potensi sumber daya manusia peternakan sapi potong di Kecamatan Sijunjung, maka dilihat sebagai berikut : umur, jenis kelamin, tingkat pendidikan, jumlah ternak yang dimilki, status kepemilikan ternak dan pengalaman beternak. 
2. Untuk menjawab tujuan penelitian yang kedua tentang ketersediaan fasilitas pendukung untuk pengembangan peternakan sapi potong di Kecamatan Sijunjung yang terdiri dari : SPIB/ULIB, PUSKESWAN, pasar ternak, RPH/TPH, kelembagaan peternak (kelompok tani ternak, asosiasi peternak, lembaga keuangan peternak).

3. Untuk menjawab tujuan penelitian yang ketiga tentang potensi lahan dan pakan di Kecamatan Sijunjung terhadap pengembangan peternakan sapi potong terdiri dari: produksi hijauan alami menurut penggunaan lahan, produksi limbah pertanian, luas lahan kering menurut penggunaannya.

4. Untuk menjawab tujuan penelitian yang keempat mengenai kemampuan wilayah Kecamatan Sijunjung untuk pengembangan peternakan sapi potong terdiri dari : kemampuan wilayah dalam menampung ternak, penambahan ternak.

\section{Analisis Data}

a. Variabel pertama dan kedua akan dianalisis secara deskriptif.Data akan disederhanakan ke dalam bentuk berupa rata-rata dan persentase. Selanjutnya untuk melengkapi diskripsi maka dilakukan analisis untuk menjelaskan dan menginterpretasikan informasi yang didapat.

b. Variabel ketiga

Untuk menghitung Indeks Daya

Dukung Wilayah digunakan rumus:

$$
\text { IDD }=\frac{\text { Total Potensi Pakan yang Tersedia (BKC) }}{\text { Total Kebutuhan Pakan (BKC) }}
$$

Total Ketersediaan Pakan Ternak (BKC)/ Tahun =Jumlah Pakan Asal Limbah Pertanian + Jumlah Produksi Hijauan Alami Menurut Penggunan Lahan

Untuk menghitung Kebutuhan pakan, digunakan rumus:

Populasi ternak (ST) x K, dimana:

$\mathrm{K}=2,5 \% \times 50 \% \times 365 \times 250 \mathrm{~kg}=1,14$ ton $\mathrm{BKC} /$ tahun/ ST

Keterangan:

$\mathrm{K}=$ Kebutuhan pakan minimum untuk 1 ST (dalam ton bahan kering tercerna atau disebut juga DDM (digestible dry matter) selama 1 tahun.
$2,5 \%=$ Kebutuhan minimum jumlah ransum hijauan pakan (bahan kering)terhadap berat badan

$50 \%=$ Nilai rata-rata daya cerna berbagai jenis tanaman

$365=$ Jumlah hari dalam satu tahun $250 \mathrm{~kg}=$ Jumlah biomassa untuk 1 satuan ternak (ST)

c. Variabel keempat

Untuk menghitung kemampuan wilayah $(\mathrm{ST})=\frac{\text { IDD }}{2} \times$ Total Populasi (ST) 
Kapasitas penambahan ternak

= Kemampuan wilayah (ST) - Populasi ruminansia (ST)

\section{HASIL DAN PEMBAHASAN}

1. Profil Sumber Daya Manusia Peternak Sapi Potong di Kecamatan Sijunjung

Profil atau karakteristik responden peternak sapi potong meliputi umur, jenis kelamin, tingkat pendidikan formal, kepemilikan ternak, pengalaman usaha sapi potong, dan jumlah ternak yang dimiliki.

\section{1) Umur}

Komposisi peternak berdasarkan umur diperlukan untuk mengetahui jumlah peternak yang produktif dan tidak produktif. Umur merupakan salah satu indikator yang menunjukkan kemampuan fisik seseorang. Orang yang memiliki umur yang lebih tua fisiknya lebih lemah dibandingkan dengan orang yang berumur lebih muda. Umur seorang peternak dapat berpengaruh pada produktifitas kerja mereka dalam kegiatan usaha peternakan. Umur juga erat kaitannya dengan pola pikir peternak dalam menentukan sistem manajemen yang akan diterapkan dalam kegiatan usaha peternakan. Sesuai dengan pendapat Adiwilaga (1982), usia produktifitas masyarakat dibedakan atas tiga golongan usia yaitu $<25$ tahun yang merupakan usia pra produktif, usia antara 25-55 tahun merupakan usia produktif, dan besar dari 55 tahun yang merupakan usia post produktif. Selanjutnya dapat dilihat pada Tabel 8 .

Tabel 1. Umur Peternak Sapi Potong di Kecamatan Sijunjung

\begin{tabular}{llll}
\hline No & $\begin{array}{l}\text { Umur } \\
\text { (tahun) }\end{array}$ & $\begin{array}{l}\text { Jumlah } \\
\text { (orang) }\end{array}$ & $\begin{array}{l}\text { Persentase } \\
(\%)\end{array}$ \\
\hline 1 & $<25$ & 0 & 0 \\
2 & $25-55$ & 32 & 82,05 \\
3 & $>55$ & 7 & 17,95 \\
\hline & Jumlah & 39 & 100,00 \\
\hline
\end{tabular}

Sumber : Hasil Pengolahan Data, 2016

Berdasarkan Tabel 8 dapat dijelaskan bahwa peternak sapi potong di Kecamatan Sijunjung 82,05\% berada pada usia produktif dan $17,95 \%$ pada usia post produktif. Hal ini menunjukkan kemampuan peternak untuk mengembangkan usaha ternak sapi potong sangat besar, dalam arti tenaga yang tersedia masih cukup kuat untuk bekerja. Peternak yang berumur produktif akan lebih efektif mengelola usahanya dibandingkan peternak yang sudah tua maupun yang masih terlalu muda (Adiwilaga, 1982).

\section{2) Jenis Kelamin}

Komposisi peternak menurut jenis kelamin dapat digunakan untuk mengetahui jumlah peternak serta besarnya sex ratio di suatu daerah, yaitu angkayang menunjukkan perbandingan jumlah peternak laki-laki dan perempuan. Perbandingan jumlah peternak laki-laki dan perempuan dapat dilihat pada Tabel.

Tabel 2. Perbandingan Jumlah Peternak Menurut Jenis Kelamin di Kecamatan Sijunjung 


\begin{tabular}{llll}
\hline No & Jenis Kelamin & $\begin{array}{l}\text { Jumlah } \\
\text { (orang) }\end{array}$ & $\begin{array}{l}\text { Persentase } \\
(\%)\end{array}$ \\
\hline 1 & Laki-laki & 18 & 46,15 \\
2 & Perempuan & 21 & 53,85 \\
\hline & Jumlah & 39 & 100 \\
\hline
\end{tabular}

Sumber : Hasil Pengolahan Data, 2016

Pada tabel di atas dapat dijelaskan bahwa jumlah peternak perempuan lebih banyak daripada peternak laki-laki yaitu $53,85 \%$ (21 perempuan) dan 46,15\% (18 laki-laki). Fakta ini menunjukkan bahwa usaha sapi potong didominasi oleh peternak perempuan.Peranan perempuan pada usaha ternak sapi potong di Kecamatan Sijunjung cukup besar pada kegiatan produktif pemeliharaan. Kegiatan produktif tersebut antara lain memberikan pakan, minum, membersihkan kandang, memandikan ternak dan kadang-kadang mencari rumput. Sedangkan untuk kegiatan lain cenderung dilakukan oleh peternak lakilaki atau suami mereka yang memiliki pekerjaan utama selain beternak seperti pedagang, buruh, dan karyawan swasta.

Peranan perempuan dengan berbagai aktifitas kerja sehari-hari baik yang dilakukan secara terencana maupun tidak pada sasarannya mempunyai nilai ekonomis, terutama bila dikaitkan dengan pendapatan dalam usaha membantu keluarga untuk menambah nafkah yang bertujuan meningkatkan kesejahteraan keluarga. Oleh karena itu perlu dukungan masyarakat yang semakin tinggi terhadap perluasan kesempatan berkarya bagi perempuan khususnya di pedesaan (Saleh dan Yunilas, 2004). Seiiring dengan itu Ratna (2000) berpendapat bahwa perempuan saat ini tidak saja berkegiatan di dalam lingkup keluarga, tetapi banyak di antara bidang-bidang kehidupan di masyarakat membutuhkan sentuhan kehadiran perempuan dalam penanganannya.

\section{3) Tingkat Pendidikan Formal}

Pendidikan merupakan salah satu faktoryang berperan penting dalam pembangunan suatu wilayah. Apabila penduduk di suatu wilayah memiliki tingkat pendidikan yang tinggi maka akan memilikikemampuan dalam pengembangan pembangunan di wilayahnya. Pendidikan di suatu wilayah dipengaruhi antara lain oleh kesadaran akan pentingnya pendidikan,keadaan sosial ekonomi, dan sarana pendidikan yang ada. Tingkat pendidikan manusia pada umumnya menunjukkan daya kreatifitas manusia dalam berfikir dan bertindak. Seiring dengan itu Soekartawi (2003) mengemukakan bahwa banyaknya atau lamanya sekolah/pendidikan yang diterima seseorang akan berpengaruh terhadap kecakapannya dalam pekerjaan tertentu. Hasyim (2003) menambahkan tingkat pendidikan formal yang dimiliki petani akan menunjukkan tingkat pengetahuan serta wawasan yang luas untuk petani menerapkan apa yang diperolehnya untuk peningkatan usaha taninya. Tingkat pendidikan formal peternak dapat dilihat pada Tabel dibawah ini.

Tabel 3. Tingkat Pendidikan Formal Peternak di Kecamatan Sijunjung

\begin{tabular}{lll}
\hline No & Pendidikan & Jumlah (orang) \\
\hline
\end{tabular}




\begin{tabular}{llll}
\hline 1 & Tidak Sekolah & 1 & 2,56 \\
2 & SD & 16 & 41,03 \\
3 & SMP & 20 & 51,28 \\
4 & SMA & 2 & 5,13 \\
\hline
\end{tabular}

Sumber : Hasil Pengolahan Data, 2016

Pada tabel di atas dapat dijelaskan bahwa tingkat pendidikan formal para peternak sebagian besar adalah lulusan sekolah menengah pertama (SMP) 51,28\%, kemudian lulusan SD, SMA, dan tidak sekolah dengan masing-masing sebesar $41,03 \%, 5,13 \%$, dan 2,56\%. Dilihat dari data diatas, tingkat pendidikan peternak di Kecamatan Sijunjung tergolong masih rendah. Tingkat pendidikan Menurut UU No 20 tahun 2003 adalah (1) pendidikan dasar/rendah adalah SD,SMP/MTs, (2) pendidikan menengah adalah SMA/SMK dan (3) pendidikan tinggi adalah D3/S1. Rendahnya tingkat pendidikan peternak di Kecamatan Sijunjung merupakan salah satu kelemahan dalam pengembangan usaha ternak sapi potong. Tingkat tinggi rendahnya pendidikan petani akan menanamkan sikap yang menuju penggunaan praktek pertanian yang lebih modern (Ibrahim dkk, 2003). Oleh sebab itu perlu ditingkatkan pendidikan maupun keterampilan peternak karena tingkat pendidikan sangat berpengaruh terhadap laju penyerapan inovasi, perubahan pola pikir, dan kepekaan terhadap perubahan sosial lainnya.

\section{4) Jumlah Ternak yang Dimiliki Responden}

Jumlah ternak menunjukkan banyaknya ternak sapi potong yang dipelihara dan dimiliki olehresponden. Usaha ternak sapi potong dalam peternakan rakyat masih merupakan usaha sampingan bagi peternak, dimana skala usahanya masih dalam skala usaha kecil. Disamping jumlah ternak yang dipelihara relatif kecil, peternakan rakyat melibatkan anggota keluarga diluar pekerjaan utamanya dalam pemeliharaan ternak. Selengkapnya dapat dilihat pada Tabel berikut:

Tabel 4. jumlah Ternak Yang Dimiliki Peternak di Kecamatan Sijunjung

\begin{tabular}{llll}
\hline No & $\begin{array}{l}\text { Jumlah Ternak } \\
\text { (ekor) }\end{array}$ & $\begin{array}{l}\text { Jumlah } \\
\text { (orang) }\end{array}$ & $\begin{array}{l}\text { Persentase } \\
(\%)\end{array}$ \\
\hline 1 & $1-5$ & 31 & 79,49 \\
2 & $6-10$ & 8 & 20,51 \\
3 & $>10$ & 0 & 0
\end{tabular}

Sumber : Hasil Pengolahan Data, 2016

Pada tabel di atas dapat dijelaskan bahwa 79,49\% peternak sapi potong di Kecamatan Sijunjung memiliki ternak sekitar 1-5 ekor.
$20,51 \%$ peternak memiliki ternak di atas 6-10 ekor. Hal ini menunjukkan bahwa usaha ternak sapi potong harus dikembangkan lebih lanjut, karena pada 
umumnya skala jumlah ternak responden masih tergolong skala kecil, sehingga untuk meningkatkan produktifitas suatu usaha peternak maka dibutuhkan peningkatan dalam jumlah ternak. Bessant (2005) berpendapat bahwa skala kepemilikan sapi potong petani peternak yang berstatus sebagai peternakan rakyat, dikelompokkan menjadi 3 bagian yaitu skala kecil (1-5 ekor), skala menengah (6-10 ekor) dan skala besar (>10 ekor). Usaha sapi potong yang dijalankan oleh peternak masih termasuk dalam usaha skala kecil. Hal ini disebabkan oleh beberapa faktor, diantaranya keterbatasan modal usaha, jenis usahanya masih merupakan usahasampingan, tenaga kerja masih melibatkan anggota keluarga diluar pekerjaan utamanya, dan cara pemeliharaannya masih bersifat tradisional. Jika dilihat dari jumlah ternak pada masing-masing peternak dapat digolongkan dalam peternakan rakyat. Hal ini sesuai dengan pendapat Fadilah dkk dalam Siregar (2008) bahwa golongan usaha peternakan yang dengan jumlah ternak skala kecil disebut juga sebagai peternakan rakyat.

\section{5) Status Kepemilikan Ternak Sapi Potong di Kecamatan Sijunjung}

Kepemilikan ternak menggambarkan asal modal yang dimiliki peternak dalam usahanya. Pada umumnya peternak sapi potong di Kecamatan Sijunjung masih merupakan skala kecil, dimana jumlah ternak yang dimiliki oleh peternak berkisar antara 15 ekor. Hal ini disebabkan oleh keterbatasan modal peternak untuk pengembangan usahanya. Adapun sumber modal bagi peternak sapi potong di Kecamatan Sijunjung dapat dilihat pada berikut:

Tabel 5. Status Kepemilikan Ternak Sapi Potong di Kecamatan Sijunjung

\begin{tabular}{llll}
\hline No & $\begin{array}{l}\text { Kepemilikan } \\
\text { Ternak }\end{array}$ & $\begin{array}{l}\text { Jumlah } \\
\text { (orang) }\end{array}$ & $\begin{array}{l}\text { Persentase } \\
(\%)\end{array}$ \\
\hline 1 & Sendiri & 27 & 69,23 \\
2 & Gaduh & 12 & 30,77 \\
\hline & Jumlah & 39 & 100,00 \\
\hline
\end{tabular}

Sumber : Hasil Pengolahan Data, 2016

Berdasarkan data diatas dapat dijelaskan bahwa $69,23 \%$ peternak di Kecamatan Sijunjung dalam usaha ternak sapi potong menggunakan modal sendiri. Kemudian $30,77 \%$ dari peternak menggunakan modal dari orang lain atau yang bisa disebut dengan sistem gaduh, dimana mengandung unsur kerjasama bagi hasil.

Usaha ternak sapi potong dengan modal sendiri sangat dominan di Kecamatan Sijunjung, peternak menggunakan modal sendiri dengan tujuan ternak sapi yang dipelihara sebagai tabungan yang sewaktu-waktu bisa dijual jika ada keperluan yang bersifat mendadak.

Meskipun demikian, peternak di wilayah ini juga banyak berminat dengan sistem gaduh yang modalnya dari orang lain. Sistem gaduh disamping mengandung unsur kerjasama bagi hasil, lebih dari itu adalah merupakan salah satu upaya dalam mengatasi kekurangan modal bagi penggaduh 
(peternak). Usaha gaduhan merupakan salah satu usaha kerjasama yang sering dilakukan di masyarakat. Usaha kerja sama ini untuk memenuhi atau menyambung keinginan sebagian masyarakat untuk beternak sapi. Hal ini biasanya terjadi bila seseorang yang memiliki modal cukup dan ingin beternak sapi, tetapi tidak ada tempat dan kurangnya pengetahuan mengenai ternak sapi.

Selain itu, pemilik modal juga tidak mau susah payah belajar ternak sapi. Oleh karena itu, pemilik modal menyerahkan sapinya untuk dipelihara pada orang yang dipercaya mampu memelihara ternak hingga ada hasilnya. Pembagian keuntungan antara pemilik modal dan penggaduh tergantung kesepakatan, bisa $50 \%$ : $50 \%$ atau $60 \%$ : $40 \%$. Bila gaduhan sampai sapi beranak, maka anak sapi yang pertama untuk penggaduh dan anak sapi kedua untuk pemilik modal (Yulianto dan Cahyo, 2010).

\section{6) Pengalaman Beternak Responden}

Pengalaman merupakan pelajaran yang sangat berharga. Semakin banyak pengalaman yang dimilki oleh peternak maka akan bijak dalam mengambil keputusan. Pengalaman beternak akan diperoleh seseorang berdasarkan lama mereka bergelut dalam suatu usaha peternakan. Pengalaman beternak merupakan faktor penting yang harus dimiliki oleh seorang peternak memutuskan segala kebijakan yang akan diterapkan dalam usaha termasuk memutuskan untuk menggunakan sumber modal. Setiap keputusan yang diambil diharapkan berpatokan dari pengalaman, baik itu pengalaman sendiri atau pengalaman dari orang lain. Pengalaman beternak peternak dapat dilihat pada Tabel dibawah ini:

Tabel 6. Pengalaman beternak Sapi Potong di Kecamatan Sijunjung

\begin{tabular}{llll}
\hline No & Lama Beternak & $\begin{array}{l}\text { Jumlah } \\
\text { (orang) }\end{array}$ & $\begin{array}{l}\text { Persentase } \\
(\%)\end{array}$ \\
\hline 1 & $<5$ Tahun & 26 & 66,67 \\
2 & 5-10 Tahun & 11 & 28,20 \\
3 & $>10$ Tahun & 2 & 5,13 \\
\hline & Jumlah & 39 & 100,00 \\
\hline
\end{tabular}

Sumber : Hasil Pengolahan Data, 2016

Pada tabel diatas pengalaman beternak tertinggi berada pada rentang waktu $<5$ tahun yaitu 26 orang dengan persentase $66,67 \%$. Berdasarkan kenyataan tersebut, maka dapat dikatakan bahwa peternak sapi potongmasih kurang berpengalaman dalam usaha peternakan sapi potong. Kurangnya pengetahuan tentang kesehatan ternak, pemanfaatan dan pemberian pakan tambahan pada ternak serta kurangnya minat dalam penanaman hijauan.Peternak yang memiliki pengalaman beternak yang cukup lama umumnya memiliki pengetahuan yang lebih banyak dibandingkan peternak yang baru saja menekuni usaha peternakan.Mastuti dan Hidayat (2008) mengatakan bahwa semakin lama beternak diharapkan pengetahuan yang didapat semakin banyak sehingga keterampilan dalam menjalankan usaha peternakan semakin meningkat. Sehingga pengalaman 
berternak menjadi salah satu ukuran kemampuan seseorang dalam mengelola suatu usaha peternakan.

\section{Fasilitas Pendukung Peternakan Sapi Potong Di Kecamatan Sijunjung \\ 1. SPIB/ ULIB}

Satuan Pelayanan Inseminasi Buatan (SPIB) dan pos IB (Inseminasi Buatan) merupakan satuan pelayanan yang berhubungan dengan reproduksi pada ternak. 8unit Pos IB terdapat di tiap kecamatan dan 1 unit SPIB di kabupaten. Sedangkan ULIB (Unit Layanan Inseminasi Buatan) merupakan unit pelayanan IB milik kelompok tani dimana jangkauan Pos IB agak jauh sehingga untuk peningkatan realisasi IB (Ditjennak,2010). Sampai tahun 2014 telah terdapat 7 lokasi ULIB. Selanjutnya dapat dilihat pada tabel berikut:

Tabel 7. Nama dan Lokasi ULIB di Kabupaten Sijunjung

\begin{tabular}{lll}
\hline No & Nama Kelompok Tani & Lokasi \\
\hline 1 & Hidup Bersama & Nagari Muara Takung Kec. Kamang Baru \\
2 & Agri Sepakat & Nagari Tanjung Bonai Aur Kec. Sumpur Kudus \\
3 & Sinar Pagi & Nagari Latang Kec.Lubuak Tarok \\
4 & Sumando Ninik Mamak & Nagari Tanjung Gadang Kec. Tanjung Gadang \\
5 & Tunas Muda & Nagari Kamang Kec.Kamang Baru \\
6 & Bukit Talago & Nagari Padang Laweh Kec.Koto VII \\
7 & Amanah & Nagari Pematang Panjang Kec. Sijunjung \\
\hline
\end{tabular}
bawah ini

Kondisi ULIB di Kecamatan Sijunjung, seperti yang tercantum pada tabel di Tabel 8. Kondisi ULIB di KecamatanSijunjung

\begin{tabular}{lll}
\hline No & Uraian & Jumlah \\
\hline 1 & Jumlah PosULIB & 1 \\
2 & Pendidikan Petugas & \\
& SMA/sederajat & 1 \\
& D3 & - \\
& S1 & 1 \\
3 & Peralatan & Lengkap \\
4 & Status Petugas & \\
& PNS & 1 \\
& Non PNS & 1 \\
5 & Fasilitas Kendaraan & 1 \\
& Dinas & 1 \\
& Pribadi &
\end{tabular}

Sumber : Hasil Penelitian, 2016 
Tabel diatas menjelaskan Petugas ULIB memilki dua orang petugas IB yang berpendidikan SMA/Sederajat dan S1 (Strata 1), masing-masing berstatus Pegawai Negeri Sipil (PNS) dan Non PNS. Peralatan yang dimiliki di Pos IB/ULIB dalam melakukan tugas inseminasi buatan pada ternak, secara keseluruhan lengkap lebih rinci dapat dilihat pada Lampiran 6.

Berdasarkan hasil penelitian, kondisi pos ULIB di Kecamatan Sijunjung sudah termasuk pada kategori baik yaitu memiliki ruang pelayanan, alat medis, alat penunjang praktik yang sesuai dengan ketentuan yang ada. Menurut Pedoman Pelaksanaan Insiminasi Buatan pada Ternak Sapi yang dikeluarkan oleh Direktorat Jenderal Peternakan dan Kesehatan Hewan (2010) syarat pendidikan inseminator minimal SMU atau sederajat, dan telah lulus pelatihan inseminasi buatan dan memenuhi kualifikasi serta memiliki SIM-I. Insiminator di Kecamatan Sijunjung berpendidikan SMA, S1 dan telah mengikuti pelatihan inseminasi buatan serta memiliki SIM-I yang merupakan syarat untuk bisa melakukan IB.
Petugas IB/inseminator tersebut sudah berstatus PNS dan masih ada yang berstatus Non PNS. Petugas yang berstatus Non PNS ini dibolehkan jika terjadi kekurangan, sebagaimana yang diatur dalam Peraturan Menteri Pertanian Nomor: 64/Permentan/OT.140/9/2007 tentang pedoman Pelayanan Pusat Kesehatan Hewan (Puskeswan).

\section{Puskeswan}

$\begin{array}{crr}\text { Pusat } & \text { Kesehatan } & \text { Hewan } \\ \text { (PUSKESWAN) } & \text { merupakan } & \text { unit }\end{array}$ pelayanan kesehatan hewan untuk masyarakat. Di kabupaten Sijunjung terdapat 3 unit puskeswan yang berada di Kecamatan Kamang Baru, Kecamatan IV Nagari dan di Kecamatan Sijunjung. Unit puskeswan di Kecamatan Sijunjung berlokasi di Nagari Muaro. Pelayanan kesehatan hewan yang dapat diperoleh antara lain pemeriksaan, pengobatan, dan vaksinasi ternak dan hewan peliharaan, rekomendasi siyx tergigit hewan tersangka rabies, penyuluhan kesehatan hewan. Berikut kondisi Puskeswan di Kecamatan Sijunjung pada Tabel dibawah ini:

Tabel 9. Kondisi Puskeswan di Kecamatan Sijunjung

\begin{tabular}{lll}
\hline No & Uraian & Kodisi \\
\hline 1 & Bangunan Kantor & Ada \\
2 & Sarana dan Peralatan & Tidak Lengkap \\
3 & Petugas & Kurang Lengkap \\
\hline
\end{tabular}

Sumber : Hasil Penelitian, 2016

Dari hasil penelitian didapatkan data bahwa puskeswan yang ada di Kecamatan Sijunjung sudah memiliki bangunan kantor. Sarana dan peralatan yang dimilki secara keseluruhan belum lengkap. Laboratorium yang ada di Puskeswan memiliki peralatan yang sederhana, seperti mikroskop, Thermometer, dan kulkas penyimpan vaksin. Status kepegawaian petugas adalah 5 (lima) orang berstatus PNS dan 3 (tiga) orang Non PNS. 
Menurut Permentan RI Nomor : 64/Permentan/OT.140/9/2007 yaitu sumber daya manusia yang bertugas di Puskeswan paling kurang terdiri atas : 1 (satu)orang Dokter Hewan, 2 (dua) orang ParamedikVeteriner, 4 (empat) orang tenaga teknis yang terdiri dari Asisten Teknis Reproduksi, Petugas Pemeriksa Kebuntingan, Inseminator dan Vaksinator, 1 (satu) orang administrasi.Puskeswan mempunyai tugas : (a) Melakukan kegiatan pelayanan kesehatan hewan di wilayah kerjanya, (b) Melakukan konsultasiveteriner dan penyuluhan di bidang kesehatan hewan, (c) Memberikan Surat Keterangan Dokter Hewan.

\section{Pasar Ternak}

Pasar adalah salah satu elemen yang sangat penting dalam sebuah usaha, termasuk usaha peternakan. Pasar dalam usaha peternakan biasanya dikenal dengan pasar ternak atau pasar hewan. Di Kecamatan Sijunjung tidak terdapat pasar ternak. Berdasarkan wawancara dari setiap peternak bahwa dari dahulu sampai sekarang peternak lebih senang dengan sistem penjualan ternak yang telah umum mereka lakukan yaitu biasanya para toke (pedagang pengumpul) langsung datang kekandang untuk membeli sapi mereka serta proses penentuan harga biasanya berdasarkan taksiran daging oleh toke (pedagang pengumpul) dan peternak sehingga tawaran yang diberikan kepada mereka di bawah harga pasar. Di kecamatan tetangga memiliki satu pasar ternak yang jaraknya dari Kecamatan Sijunjung 3-10 Km. Lokasi pasar ternak berada di Nagari Palangki Kecamatan IV Nagari yang bernama Pasar Ternak Palangki. Pasar ternak ini adalah Pasar Ternak Kabupaten dan merupakan pasar tenak terbesar di Sumatera Barat.
Transportasi yang susah untuk menjangkau pasar ternak tersebut maka, masyarakat yang berada di pedalaman hanya mencari posisi main yang aman saja yaitu menjual ternaknya ke toke (pedagang pengumpul). Untuk itu, sebaiknya perlu didirikan pasar ternak ini agar terjadi daya tawar harga yang kuat sehingga didapatkan harga sesuai dengan pasaran dan peternak pun tidak merasa dirugikan.

\section{Rumah Potong Hewan}

Rumah Potong Hewan (RPH) adalah suatu komplek bangunan dengan desain dan persyaratan-persyaratan teknis tertentu yang dipergunakan sebagai tempat memotong hewan dan penanganan serta pemprosesan dagingnya secara benar bagi konsumsi masyarakat luas (Dinas Peternakan, 2005).Kecamatan Sijunjung tidak memiliki RPH, belum adanya RPH disebabkan beberapa faktor diantaranya belum adanya rekomendasi dari pemerintah untuk mendirikan RPH karena kemungkinan belum banyaknya permintaan dari masyarakat.

Selain RPH juga terdapat Tempat Pemotongan Hewan (TPH) milik pemerintah. Di Kecamatan Sijunjung terdapat satu TPH yang berlokasi di Jorong Kampung Baru Nagari Sijunjung.Peternak dan masyarakat belum memaksimalkan penggunaanTPH, diantaranya masih melakukan pemotongan ternak di rumah-rumah para toke(pedagang pengumpul) ternak.

TPH yang ada masih jauh dari standar tempat potong hewan yang ditetapkan pemerintah. Tidak ada pembagian daerah bersih dan daerah kotor, tidak ada ruang pendinginan dan pembekuan, tidak ada ruangan pengemasan daging dan tidak diterapkannya berbagai persyaratan 
teknis lainnya. Kondisi yang lebih parah terjadi pada pemotongan di rumahrumah toke/agen/pemilik ternak.

Dengan kondisi TPH tersebut, akan membuat daging yang dihasilkan tidak terjamin keASUHannya. ASUH merupakan singkatan dari aman, sehat, utuh dan halal yang merupakan cita-cita yang ingin diwujudkan pemerintah dalam memproduksi pangan asal ternak.

\section{Kelembagaan Peternakan \\ a. Kelompok Tani Ternak}

Berdasarkan Penelitian didapatkan data kondisi kelompok tani ternak di Kecamatan Sijunjung, dapat dilihat pada tabel berikut:

Tabel 10. Jumlah dan Kelas Kelompok Tani Ternak di Kecamatan Sijunjung

\begin{tabular}{llll}
\hline No & Kelas Kelompok & Jumlah & Persentase $(\%)$ \\
\hline 1 & Pemula & 51 & 36,17 \\
2 & Lanjut & 78 & 55,32 \\
3 & Madya & 12 & 8,51 \\
4 & Utama & 0 & 0 \\
\hline & Total & 141 & 100 \\
\hline
\end{tabular}

Sumber : Hasil Penelitian, 2016

Tabel diatas menjelaskan bahwa kelompok tani ternak yang ada di Kecamatan Sijunjung pada umumnya termasuk kelompok lanjut (55,32\%), kelompok pemula $(36,17 \%)$, kelompok madya $(8,51 \%)$ dan tidak ada kelompok utama. Dari penjelasan tersebut, dapat disimpulkan bahwa kelompok tani ternak yang ada di Kecamatan Sijunjung sudah berada pada kelas lanjutan. Menurut Soedijanto (1999) mengatakan pengelompokan petani yang bermacam-macam mendasarkan pada kemampuan kelompok tani yang dapat dikasifikasikan menjadi empat kelompok tani yaitu:

1) Kelas pemula memiliki cir-ciri : kontak tani belum aktif, dalam taraf pembentukan kelompok tani, pemimpin formal aktif, kegiatan kelompok bersifat informatif.

2) Kelas lanjut ciri-cirinya kelompok inti menyelenggarakan demfarm(demonstrasi farming) dan gerakan-gerakan terbatas, kegiatan kelompok dalam perencanaan (terbatas), pemimpin formal aktif, kontak tani mampu memimpin gerakan kerjasama dengan kelompok tani.

3) Kelas madya ciri-cirinya kelompok tani menyelenggarakan kerjasama usaha tani sehamparan, pemimpin formal kurang menonjol, kontak tani dan kelompok inti bertindak sebagai pemimpin kerjasama usaha tani sehamparan dan berlatih 


\section{mengembangkan program sendiri. \\ 4) Kelas utama merupakan kelompok tani yang telah mandiri dan memiliki hubungan baik dengan lembaga lainnya, memiliki program tahunan untuk meningkatkan produksi, pendapatan dan pemupukan modal.}

\section{b. Asosiasi Peternak}

Asosiasi peternak merupakan kerjasama tim dalam membangun usaha peternakan. Keberhasilan pembangunan agribisnis peternakan akan sangat ditentukan keharmonisan kerjasama tim (team work) sumber daya manusia (SDM) baik yang berada pada agribisnis hulu, budi daya, agribisnis hilir dan yang ada pada jasa penunjang. Untuk membangun sumber daya yang bermutu, kita perlu mengembangkan suatu sistem pembangunan mutu sumberdaya manusia yang ada untuk memiliki wawasan aspek mikro, makro dan global dari agribisnis (Saragih, 2000).

Berdasarkan wawancara dengan petugas di Dinas Peternakan Kabupaten Sijunjung pada tahun 2015 tidak terdapat asosiasi peternak di Kecamatan Sijunjung, artinya peternak menyelesaikan masalah yang dihadapi dengan segala kemampuan yang ada. Hal ini menjadi masalah yang harus dipikirkan dan ditangani oleh seluruh stakeholder peternakan secara serius sehingga peternak sapi di Kecamatan Sijunjung menikmati hasil jerih payahnya dengan adil.

\section{c. Lembaga Keuangan}

Lembaga keuangan berfungsi sebagai tempat penyimpanan uang dan peminjaman uang bagi masyarakat. Lembaga keuangan juga berfungsi dalam menyalurkan bantuan kredit dari pemerintah untuk peternak. Di Kecamatan Sijunjung terdapat Bank Pemerintah dan Bank Pembangunan Daerah, 2 Bank Swasta dan 2 Bank Perkeriditan Rakyat yang berada di Nagari Sijunjung dan Nagari Pematang Panjang. Selain bank, juga terdapat koperasi yang tersebar di pelosok nagari. Menurut data BPS (2015) terdapat 50 unit koperasi dengan total anggota 8.994 orang anggota. Koperasi tersebut terbagi atas koperasi serba usaha, koperasi unit desa, koperasi pertanian dan koperasi lainnya.

Pada Bank Pemerintah terdapat program kredit/pinjaman bunga rendah seperti Kredit Ketahanan Pangan dan Energi (KKPE) dan Kredit Usaha Peternakan Sapi (KUPS).

\section{Indeks Daya Dukung Wilayah}

Untuk mengetahui indeks daya dukung wilayah terhadap pengembangan peternakan sapi, dapat diukur dengan menghitung total potensi pakan yang tersedia dibagi dengan total kebutuhan pakan.

\section{Potensi Pakan yang Tersedia}

Pakan ternak dapat dihasilkan dari pakan asal limbah pertanian dan hijauan alami yang tersedia di lahan yang ada. Limbah pertanian yang dapat digunakan sebagai pakan ternak adalah padi sawah, jagung, kedelai, kacang hijau, kacang tanah, ubi jalar dan ubi kayu.Di Kecamatan Sijunjung limbah pertanian yang dapat digunakan sebagai pakan ternak adalah limbah padi dan ubi kayu, dikarenakan tidak adanya petani yang mengusahakan selain tanaman tersebut, serta kondisi wilayah yang kurang mendukung dalam mengusahakannya. Adapun pakan asal limbah pertanian di Kecamatan 
Sijunjung dapat dilihat pada tabel berikut:

Tabel 11. Potensi Pakan Asal Limbah Pertanian di Kecamatan Sijunjung

\begin{tabular}{|c|c|c|c|c|c|}
\hline No & $\begin{array}{l}\text { Jenis Limbah } \\
\text { Tanaman Pangan }\end{array}$ & $\begin{array}{l}\text { Produksi } \\
\text { Tanaman } \\
\text { (Ton/tahun) }\end{array}$ & $\begin{array}{l}\text { Produksi } \\
\text { limbah } \\
\text { (Ton/tahun) }\end{array}$ & $\begin{array}{l}\text { Daya } \\
\text { Cerna }\end{array}$ & $\begin{array}{l}\text { Produksi } \\
\text { Limbah } \\
\text { BKC Ton }\end{array}$ \\
\hline 1 & Padi Sawah & 20.895 & $20.895,0$ & 0,2 & $4.179,00$ \\
\hline 2 & Ubi Kayu & 120 & 7,5 & 0,3 & 2,25 \\
\hline & Total & & & & $4.181,25$ \\
\hline
\end{tabular}

Sumber : Hasil Pengolahan Data, 2016

Dari tabel diatas dapat terlihat bahwa limbah pertanian di Kecamatan Sijunjung dapat menghasilkan pakan ternak sebesar 4.181,25 ton BKC. Sementara itu hijauan yang dapat diproduksi oleh lahan yang ada dapat dilihat dari lahan sawah, lahan kering, perkebunan (karet, sawit, kelapa), pekarangan, tegalan, hutan, padang pengembalaan dan lain-lainnya. Selengkapnya dapat dilihat pada tabel berikut

ini.

Tabel 12. Produksi Hijauan Alami Menurut Penggunaan Lahan di Kecamatan Sijunjung

\begin{tabular}{|c|c|c|c|c|c|}
\hline No & $\begin{array}{l}\text { Penggunaan } \\
\text { han }\end{array}$ & $\begin{array}{l}\text { Luas } \\
\text { Lahan } \\
(\mathrm{Ha})\end{array}$ & $\begin{array}{l}\text { Produktivitas } \\
\text { Pakan } \\
\text { hijauan } \\
\text { (ton/m/tahun) }\end{array}$ & $\begin{array}{l}\text { Faktor } \\
\text { Konservasi }\end{array}$ & $\begin{array}{l}\text { Produksi } \\
\text { (ton BKC/tahun) }\end{array}$ \\
\hline (a) & (b) & (c) & (d) & (e) & $\mathrm{f}=(\mathrm{c}) *(\mathrm{~d}) *(\mathrm{e}) * 0.5$ \\
\hline 1 & Sawah & $3.358,00$ & 1,250 & 1,0 & $2.098,75$ \\
\hline 2 & Lahan Kering & $5.762,00$ & 2,975 & 1,5 & $12.856,46$ \\
\hline \multirow[t]{4}{*}{3} & Perkebunan & & & & \\
\hline & Karet & $9.322,00$ & 2,000 & 1,5 & $13.983,00$ \\
\hline & Sawit & 113,00 & 2,000 & 1,5 & 169,50 \\
\hline & Kelapa & 465,00 & 5,000 & 1,5 & $1.743,75$ \\
\hline 4 & Pekarangan & 245,00 & 0,530 & 2,0 & 129,85 \\
\hline 5 & Tegalan & 401,50 & 2,875 & 1,0 & 577,16 \\
\hline 6 & Hutan & $39.425,25$ & 0,600 & 1,0 & $11.827,57$ \\
\hline \multirow[t]{2}{*}{7} & Padang & & & & \\
\hline & Pengembalaan & $3.609,00$ & 5,000 & 1,0 & $9.022,50$ \\
\hline \multirow[t]{2}{*}{8} & Lain-lain & 24,00 & 0,750 & 1,0 & 9,00 \\
\hline & Total & $62.724,75$ & 22,980 & 13,0 & $52.417,54$ \\
\hline
\end{tabular}

Sumber : Hasil Pengolahan Data, 2016

Produksi hijauan alami yang dihasilkan oleh lahan yang ada di Kecamatan Sijunjung adalah 52.417,54 ton BKC. Setelah diketahui potensi pakan asal limbah pertanian pertanian dan produksi hijauan alami menurut penggunaan lahan, maka di dapatkan total ketersediaan pakan di Kecamatan Sijunjung yaitu sebesar $52.419,33$ ton BKC/tahun. Dapat dilihat pada tabel berikut: 
Tabel 13. Total ketersediaan Pakan Ternak di Kecamatan Sijunjung (ton/BKC/tahun)

\begin{tabular}{lll}
\hline No & Potensi Pakan & Jumlah (ton/BKC/tahun) \\
\hline 1 & Asal Limbah Pertanian & $4.181,25$ \\
2 & Produksi Hijauan Alami & $52.417,54$ \\
\hline & Total & $56.598,79$ \\
\hline
\end{tabular}

Sumber : Hasil Pengolahan Data, 2016

\section{Kebutuhan Pakan Ternak}

Berdasarkan rumus yang terdapat pada metodologi penelitian, maka didapatkan kebutuhan pakan ternak ruminansia yaitu $6.874,99$ ton BKC/tahun. Dapat dilihat pada tabel berikut:

Tabel 14. Kebutuhan Pakan Ternak Ruminansia di Kecamatan Sijunjung (ton/BKC/tahun)

\begin{tabular}{|c|c|c|c|c|c|c|}
\hline No & $\begin{array}{l}\text { Jenis } \\
\text { Ternak }\end{array}$ & $\begin{array}{l}\text { Jumlah } \\
\text { (Ekor) }\end{array}$ & $\begin{array}{l}\text { Faktor } \\
\text { Konversi }\end{array}$ & $\begin{array}{l}\text { Jumlah } \\
\text { (ST) }\end{array}$ & $\begin{array}{l}\text { Kebutuhan } \\
\text { Pakan/ST } \\
(1,14 \mathrm{BKC} / \\
\text { ST/tahun })\end{array}$ & $\begin{array}{l}\text { Total } \\
\text { Kebutuhan } \\
\text { Pakan } \\
\text { (tonBKC } \\
\text { ST/tahun ) }\end{array}$ \\
\hline 1 & $\begin{array}{l}\text { Sapi } \\
\text { Potong } \\
\text { Sapi }\end{array}$ & 3.691 & 0,70 & $2.583,70$ & 1,14 & $2.945,42$ \\
\hline 2 & Perah & 2 & 0,70 & 1,40 & 1,14 & 1,60 \\
\hline 3 & Kerbau & 4.053 & 0,80 & $3.242,40$ & 1,14 & $3.696,34$ \\
\hline 4 & Kambing & 2.728 & 0,06 & 163,68 & 1,14 & 186,60 \\
\hline 5 & Domba & 790 & 0,05 & 39,50 & 1,14 & 45,03 \\
\hline & Total & 11.264 & 2,31 & $6.030,68$ & & $6.874,99$ \\
\hline
\end{tabular}

Sumber : Hasil Pengolahan Data, 2016

Dari potensi pakan ternak yang tersedia sebesar 56.598,79 ton BKC/tahun, sampai saat ini baru termanfaatkan oleh ternak ruminansia sebesar 6.874,99 ton BKC/tahun $(12,15 \%)$. Artinya masih tersedia pakan sebesar 49.723,8 ton BKC/tahun $(87,85 \%)$ untuk penambahan populasi dan pengembangan ternak di Kecamatan Sijunjung.

Indeks Daya Dukung (IDD) adalah angka yang menunjukkan status nilai daya dukung pada suatu wilayah (Ardhani, 2008). Menurut Malau (2007) IDD mempunyai 4 (empat) kriteria antara lain:

a. Wilayah sangat kritis, yaitu wilayah dengan $\quad$ IDD $\leq 1$

b. Wilayah kritis, yaitu wilayah dengan IDD $<1-1,5$

c. Wilayah rawan, yaitu wilayah dengan IDD $=2$

d. Wilayah Aman, yaitu wilayah dengan IDD > 2 
IDD didapatkan dengan membagi total potensi pakan yang tersedia dengan total kebutuhan pakan, sehingga didapatkan nilai IDD 8,23. Nilai ini artinya Kecamatan Sijunjung berada di wilayah Aman dalam pengembangan peternakan sapi potong karena memiliki IDD > 2. Aman dalam pengembangan sapi potong dapat dilihat dari semua daya dukung potensi pakan yang tersedia.

\section{Kemampuan Wilayah dalam Pengembangan Peternakan Sapi Potong}

Setelah dilakukan penghitungan menggunakn rumus seoerti yang terdapat pada metodologi, maka didapatkannilai IDD 8,23 dengan kemampuan wilayah Kecamatan Sijunjung menampung ternak ruminansia yaitu sebesar 24.816,248 ST. Saat ini populasi ternak ruminansia di Kecamatan Sjunjung adalah 6.030,68 ST. Dengan demikian masih bisa dilakukan penambahan populasi ternak mencapai 18.785,568 ST. Populasi sapi potong $33 \%$ dari total populasi ternak ruminansia. Sehingga Kecamatan Sijunjung dapat menampung 6.199,24 ST ternak sapi. Saat ini populasi sapi adalah 2.583,7 ST sehingga masih berpotensi dilakukan penambahan ternak sapi sebesar 3.615,54 ST.

\section{KESIMPULAN DAN SARAN}

\section{Kesimpulan}

Berdasarkan hasil dari penelitian dapat disimpulkan bahwa:

1. Karakteristik sumber daya manusia peternak di Kecamatan Sijunjung pada umumnya berusia produktif $(82,05 \%)$, ratarata berpendidikan SMP $(51,28 \%)$, sapi yang dipelihara merupakan milik sendiri $(69,23 \%)$, berjenis kelamin perempuan $(53,85 \%)$, dengan rata-rata jumlah ternak yang dimiliki 1-5 ekor $(79,49 \%)$, dan memiliki pengalaman beternak $<5$ tahun $(66,67 \%)$.

2. Fasilitas pendukung peternakan seperti Puskeswan dan RPH, TPH pada umumnya belum sesuai ketentuan kecuali PosULIB. Kecamatan Sijunjung tidak memiliki pasar ternak. Pada umumnya kelompok tani ternak adalah kelompok lanjut $(55,32 \%)$, tidak ada asosiasi peternak, dan terdapat 1 Bank Pemerintah, 1 Bank Pembangun daerah, 2 Bank Swasta, 2 Bank Perkeriditan Rakyat dan 50unit koperasi yang tersebar di seluruh Kecamatan Sijunjung.

3. Nilai Indeks Daya Dukung (IDD) pakan di Kecamatan Sijunjung adalah 8,23, artinya IDD $>2$ berada di wilayah aman dalam pengembangan peternakan sapi potong.

4. Kemampuan wilayah dalam menampung ternak ruminansia adalah 24.816,248 ST. Saat ini populasi ternak sebanyak 6.030,68 ST, sehingga bisa dilakukan penambahan ternak sebanyak 18.785,568 ST. Untuk populasi sapi potong dapat dilakukan penambahan sebanyak 3.615,54 ST. Kecamatan Sijunjung memiliki potensi dalam pengembangan sapi potong.

\section{Saran}

1. Pemerintah, masyarakat umum maupun investor dapat memanfaatkan potensi yang ada dapat segera dan secara maksimal, jika tidak akan percuma dan tidak membantu 
dalam upaya peningkatan kesejahteraan rakyat

2. Pengelolaan usaha yang dilakukan dapat dikelola lebih baik.

\section{DAFTAR PUSTAKA}

AAK. 1991. Petunjuk Beternak Sapi Potong dan Kerja. Penerbit Kanisius: Yogyakarta.

Abidin, Z. 2002. Penggemukan Sapi Potong; Kiat Mengatasi Permasalahan Praktis.Agromedia Pustaka: Jakarta.

Adiwilaga, A. 1982. Ilmu Usaha Tani. Penerbit Alumni, Bandung.

Atmiyati. 2006. Daya Dukung Hijauan Pakan terhadap Pengembangan Ternak di Kabupaten Sambas. Temu Teknis Nasional Tenaga fungsional Pertanian. Pusat Penelitian dan Pengembangan Peternakan.

Badan Pusat Statistik Kabupaten Sijunjung. 2015. Sijunjung Dalam Angka. Badan Pusat Statistik Kabupaten Sijunjung.

Bessant, Wijayanti BT. 2005. Analisa Usaha Peternakan Sapi Potong Dalam Kaitannya Dengan Kesejahteraan Peternak di Kabupaten dan Kota Bogor. Program Persetujuan Manajemen dan Bisnis. Skripsi. IPB, Bogor.

Daniel, M. 2002. Pengantar Ekonomi Pertanian. Bumi Aksara: Jakarta.

Dinas Peternakan Propinsi Sumatera Barat. 2005. Standar Rumah Potong Hewan. Dinas
Peternakan Propinsi Sumatera Barat. Padang.

Dinas Peternakan Kabupaten Sijunjung. 2014. Populasi Ternak Sapi Potong. Dinas Peternakan Kabupaten Sijunjung. Muaro Sijunjung.

Fauziyah, O.T. H. 2007. Prospek pengembangan usaha peternakan sapi potong di Kecamatan Bawang Kabupaten Banjarnegara. Fakultas Peternakan Institut Pertanian Bogor. Bogor.

Gustiningsih. 2008. Analisis Potensi Pengembangan Usaha Sapi Potong di Kota Sawahlunto. Skripsi. Fakultas Peternakan Universitas Andalas. Padang.

Hasibuan, Malayu S. P. 2005. Manajemen Sumber Daya Manusia, Edisi Revisi. Bumi Aksara: Jakarta.

Mastuti, S dan Hidayat, N. N. 2008. Peranan Tenaga Kerja Perempuan Dalam Usaha Ternak Sapi Perah. Jurnal of animal production: Purwokerto.

Mosher, A. T. 1991. Menggerakkan dan Membangun Pertanian, Syarat-syarat Pokok dan Modernisasi. CV. Yasaguna: Jakarta.

Paturocman. 2005. Hubungan Antara Tingkat Pendapatan Keluarga peternak dengan Tingkat konsumsi (kasus di Koperasi Peternakan Bandung Selatan (KPBS) Pangalengan). Dalam situs

www.resources.unpad.ac.id. Diakses 02 - 04 - 2016; 13.15 
Putra. 2009. Analisis Potensi Wilayah Untuk Pengembangan Usaha Sapi Potong Di Kecamatan Bayang Utara Kabupaten Pesisir Selatan. Skripsi. Universitas Andalas. Padang.

Singarimbun, M. dan E. Sofian. 1995. Metode Penelitian Survei. LP3ES. Jakarta.

Soekartawi. 1991. Agribisnis Teori dan Aplikasinya. PT. Raja Grafindo Persada: Jakarta.

2002. Prinsip Dasar Ekonomi Pertanian. PT. Raja Grafindo Persada: Jakarta.

Sugeng, Y. B. 1999. Sapi Potong. Cetakan ke-7. PT. Penebar Swadaya Jakarta Sugiyono. 2010. Metode penelitian Pendidikan. Alfabeta: Bandung.

Utomo, R. 1999. Teknologi Pakan Hijauan. Fakultas Peternakan Universitas Gajah Mada. Yogyakarta. 